\title{
Studi Moratorium Sebagai Upaya Perlindungan Pengiriman TKI Berdasarkan UU Nomor 39 Tahun 2004 di Madura
}

\author{
Ahmad Agus Ramdlany, Devi Rahayu \\ Fakultas Hukum UniversitasTrunojoyo Madura \\ rahayudevi78@yahoo.com
}

\begin{abstract}
The number of cases affecting the workers prompted the Indonesian government to undertake moratorium / suspension sending workers. Policy enforcement moratorium on sending workers to countries taken as a policy which is expected to provide protection for workers. Under the provisions of Law No. 39 of 2004 section 81 subsection (1) to justify the moratorium policy taken by the government. In fact the implementation of the moratorium in some countries turns out to further improve and increase the number of illegal workers in the area unemployed workers pockets. This study aims to determine the basis of the moratorium policy settings both theoretically and statutory regulations. The research method used is a normative approach. Data obtained included primary data and secondary data. Primary data obtained from the study of documents. While the secondary data obtained by using legal expert opinion. Data analysis with content analysis.
\end{abstract}

\section{Keywords : moratorium, protection, TKI}

Banyaknya kasus yang menimpa para TKI mendorong pemerintah Indonesia untuk melakukan kebijakan moratorium/penghentian pengiriman TKI. Pemberlakuan kebijakan moratorium pengiriman TKI ke beberapa negara diambil sebagai sebuah kebijakan yang diharapkan mampu memberikan perlindungan bagi TKI. Dalam ketentuan Pasal 81 ayat (1) UU No 39 Tahun 2004 membenarkan kebijakan moratorium yang diambil oleh pemerintah. Kenyataannya pemberlakuan moratorium di beberapa negara ternyata semakin meningkatkan jumlah TKI ilegal dan menambah pengangguran di daerah kantong TKI. Penelitian ini bertujuan untuk mengetahui dasar pengaturan kebijakan moratorium baik secara teori maupun peraturan perundang-undangan. Metode penelitian yang digunakan adalah pendekatan normatif . Data yang diperoleh meliputi data primer dan data sekunder. Data primer didapat dari studi literatur. Sedangkan data sekunder didapat dengan menggunakan pendapat ahli hukum. Analisa data dilakukan dengan content analysis.

\section{Kata kunci : moratorium, perlindungan, pengiriman TKI}

\section{Pendahuluan}

Maraknya permasalahan yang terjadi pada TKI sebenarnya merupakan realitas klasik yang terjadi pada masyarakat ekonomi lemah. Dengan tingkat pendidikan yang rendah, tidak memiliki keahlian, kemiskinan dan lapangan kerja yang terbatas di daerah mendorong banyak orang memilih menjadi TKI dengan gaji yang tinggi dan jenis kerja yang mudah (domestic worker). Adapun jenis kasus yang 
dialami TKI secara umum dimulai pra pemberangkatan, pemberangkatan dan pemulangan, saat di negara tujuan, saat pemulangan dan saat kembali di keluarga. Namun demikian apabila dicermati, untuk TKI perempuan, lebih banyak yang menjadi korban karena 'keperempuanannya', tidak demikian dengan TKI laki-laki, mereka lebih banyak menjadi korban penipuan, tidak diberangkatkan, jenis pekerjaan dan upah yang berbeda antara yang mereka terima dan yang dijanjikan.

Telah tujuh belas tahun UU Nomor 39 Tahun 2004 tentang Penempatan dan Perlindungan TKI di Luar Negeri (selanjutnya disebut UU PPTKILN) diberlakukan, tetapi masalah dan kasuskasus yang terjadi masih banyak baik secara kuantitas maupun variasinya, di samping jumlah Tenaga Kerja Indonesia (TKI) yang bekerja di luar negeri makin bertambah dari tahun ke tahun.

Penghentian atau moratorium pengiriman TKI perempuan nonformal merupakan upaya pemerintah untuk mendesak pemerintah negara penerima/negara tujuan agar mau membuat MoU yang mampu memberikan perlindungan hukum bagi TKI. Kebijakan moratorium di Arab Saudi bukanlah kebijakan pertama kali yang dilakukan karena Indonesia telah menetapkan kebijakan moratorium sebelumnya dengan pemerintah Kuwait, Suriah, dan Malaysia. Untuk negara Malaysia kebijakan moratorium telah dicabut sejak Malaysia dan Indonesia menyepakati MoU untuk tentang pekerja informal yang menyangkut pemberian hari libur, paspor dipegang sendiri oleh pekerja, upah minimum, dan biaya penempatan. Hakekatnya jika pemerintah mentaati ketentuan Pasal 27 ayat (1) UU PPTKILN, yang menyatakan penempatan TKI di luar negeri hanya dapat dilakukan ke negara tujuan yang pemerintahannya telah mempunyai perjanjian tertulis dengan pemerintah Indonesia.

Kebijakan moratorium sendiri telah diatur dalam Pasal 81 ayat (1) UU PPTKILN yang bertujuan untuk melindungi CTKI. Yang patut dicermati selama pemberlakuan moratorium di Malaysia angka pengiriman TKI Ilegal justru mengalami peningkatan. Hal ini tentunya bukan merupakan tujuan dari pemerintah. Namun, ketika menjadi TKI merupakan solusi untuk keluar dari kemiskinan, maka masyarakat akan melakukan tindakan apapun agar dapat bekerja ke luar negeri. Akibat selanjutnya dari TKI ilegal adalah adanya deportasi terhadap TKI tidak berdokumen. Menurut data KBRI Kuala Lumpur, pada tahun 2010 setidaknya ada 28.745 orang TKI yang di deportasi 
dari Malaysia. Untuk deportasi yang ditangani BNP2TKI Jawa Timur terbesar adalah dari Madura. Daerah Madura yang merupakan salah satu kantong TKI dengan tujuan utama Malaysia dan Arab Saudi, kebijakan morotaroium tentunya membawa dampak bagi masyarakat yang ingin bekerja ke luar negeri. Dengan adanya moratorium per Agustus mendatang, 1520 ribu tenaga kerja yang biasanya dikirimkan ke Saudi tidak bisa disalurkan. Tujuan dari penulisan ini adalah untuk mengetahui dasar pengaturan kebijakan moratorium baik secara teori maunpun aturan perundangundangan

\section{Metode Penelitian}

\section{Pendekatan Penelitian}

Jenis penelitian pada penelitian ini adalah normatif. Pendekatan yang dilakukan adalah pendekatan perundangundangan (statute approach) dan pendekatan kasus (case approach). Penelitian normatif dilakukan untuk menemukan hukum positif yang mengatur proses penempatan dan perlindungan TKI yang selama ini dilakukan.

\section{Jenis dan sumber data}

Data primer, yaitu data tentang: a. Dokumen peraturan perundangundangan dan peraturan daerah terkait perlindungan TKI.

b. Dokumen-dokumen Program perlindungan TKI yang dimiliki oleh pemerintah daerah.

Data Sekunder, yang terdiri atas pendapat para ahli hukum.

\section{Teknik Pengumpulan data}

Adapun teknik pengumpulan data yang digunakan penulis meliputi :

Data primer menggunakan teknik studi pustaka. Berbagai artikel dalam surat kabar, tulisan dalam majalah atau jurnal, buku-buku yang relevan akan dikaji, dan situs-situs internet, dipadukan dan dijadikan sebagai kerangka teori dari penelitian ini. Program kerja Instansi Pemerintah dan organisasi sosial di wilayah Kabupaten Bangkalan dan Sampang.

\section{Teknik analisis data}

Data penelitian pada penelitian hukum normatif berupa bahan hukum yang berkaitan dengan pengaturan dan perlindungan TKI yang telah disusun secara sistematis, kemudian diklasifikasi sesuai pokok bahasan. Selanjutnya bahan-bahan hukum tersebut dilakukan analisis secara normatif dan content analysis dengan menggunakan pendekatan peraturan perundangundangan, pendekatan konseptual, 
pendekatan komparatif dan pendekatan historis sehingga diperoleh gambaran yang menyeluruh mengenai jawaban atas permasalahan mengenai bagaimana pelaksanaan perlindungan hukum bagi TKI.

Berdasarkan analisis dan pembahasan terhadap bahan-bahan hukum yang diperoleh dalam penelitian ini, dapat ditarik beberapa kesimpulan dan diajukan saran-saran yang dipandang perlu.

\section{Hasil Dan Pembahasan}

\section{Migrasi dan Pembangunan}

Menurut The Special Rapporteur of the Commission on Human Rights kriteria seseorang disebut migran adalah (1) orang yang berada di luar wilayah negara dimana ia menjadi warga negara, tidak menjadi subjek dari perlindungan hukum negara tersebut; (2) orang yang tidak menikmati pemenuhan hak-hak dalam negaranya dan pindah ke negara lain (refugee); (3) orang yang tidak menikmati proteksi hak-hak mendasarnya dalam perjanjian diplomatik serta perjanjian lain yang disepakati negaranya (Migration, 2010) Menurut Jayati Gosh, migrasi adalah fenomena multidimensi yang memiliki dampak positif dan negatif. Dampak positifnya adalah dapat meningkatkan kesempatan untuk pekerjaan produktif dan membawa ke perspektif yang lebih luas tentang isu-isu sosial di antara migran dan populasi di negara tujuan. Sementara itu dampak negatif dari migrasi adalah memungkinkan terjadinya abuse buruh migran yang dilakukan oleh majikan dan lain-lain (Ghosh, 2010)

Migrasi terdiri dari beberapa tipe (Ghosh, 2010), di antaranya adalah (1) migrasi permanen, adalah migrasi yang dilakukan dari satu negara ke negara lain tanpa ada niatan untuk kembali menetap di negara asal, (2) return migration, seseorang bermigrasi dan kembali ke negara asal baik secara sukarela maupun tidak setelah tinggal paling tidak satu tahun di negara lain, (3) forced migration, perpindahan yang dilakukan secara paksa dan biasanya sebagai akibat dari kejadian seperti bencana alam, konflik bersenjata atau pemindahan lain. (4) irregular migration, perpindahan yang dilakukan secara ilegal, seperti smuggling yang dilakukan untuk mendapatkan keuntungan materi atau trafficking yang dilakukan secara paksa oleh agen tertentu. (5) very short-term or seasonal migration, perpindahan dilakukan untuk mendapatkan pekerjaan yang lebih baik, dilakukan oleh buruh atau pekerja.

Migrasi dan pembangunan masih menjadi yang menjadi perdebatan para 
akademisi yaitu apakah migrasi negara asal yang menjadi alasan mendorong pembangunan negara asal atau sebaliknya malah menghalangi pembangunan ?. Jika berkaca kepada sejarah yang terjadi pada tahun 19701980an, kegagalan strategi exportoriented industrialization (EO) dan structural adjustment programs (SAP) yang dilakukan oleh IMF dan Bank Dunia di negara dunia ketiga di Asia mengakibatkan krisis ekonomi, meningkatnya utang luar negeri dan tingkat pengangguran yang berdampak akhir kepada meningkatnya kemiskinan (Migration and Development, 2010). Untuk keluar dari masalah ini, banyak orang Asia yang menjadi buruh migran ke negara-negara berkembang. Tampaknya hal ini cukup membantu, paling tidak mengurangi jumlah pengangguran dan meningkatkan pendapatan negara.

Neoclassical theory adalah teori migrasi yang fokus kepada push and pull factors sebagai faktor-faktor seseorang melakukan migrasi. Castells mengatakan secara singkat teori ini menekankan perpindahan dari tempat yang padat penduduk ke tempat yang lebih renggang atau dari low-income areas ke tempat yang siklus bisnisnya fluktuatif atau high-income area (Castles dan Miller, 2009 : 22). Faktor pendorong adalah kondisi-kondisi di

seseorang untuk pindah demi mendapatkan kehidupan yang lebih baik, contohnya adalah bencana alam, ketidakstabilan politik dan ekonomi, pertumbuhan demografis, standar hidup yang rendah, demokrasi yang rendah, dan lain-lain. Sementara itu faktor penarik adalah kondisi-kondisi di negara tujuan yang terlihat lebih baik dibandingkan di negara asalnya dan membuat orang tertarik untuk pergi ke negara tersebut, seperti kebutuhan negara tersebut akan tenaga kerja, tingkat kehidupan yang lebih baik, stabilitas ekonomi dan politik, dan lainlain. Berdasarkan teori ini, keputusan seseorang untuk pindah adalah keputusan rasional yang dilakukan dengan menghitung cost and benefit demi memperoleh income maximization (Massey, 2008 : 21). Selain itu menurut teori ini, seseorang melakukan migrasi juga untuk individual maximalize utility yaitu usaha seseorang untuk memaksimalkan potensi mereka demi memperoleh apa yang di sebut sebagai human capital. Maksudnya adalah seseorang memutuskan untuk berinvestasi lewat migrasi. Mereka berinvestasi dalam pendidikan atau pelatihan vokasi dan akan bermigrasi jika hasil (pendapatan) yang diharapkan lebih besar daripada effort yang 
dikeluarkan untuk bermigrasi (Castles dan Miller, 2009 : 22).

\section{Perjanjian Kerja}

Dalam pada itu implementasi dari hak azasi untuk mendapatkan pekerjaan dan penghidupan yang layak bagi dirinya, seseorang yang tidak bekerja secara mandiri akan melakukan pekerjaan untuk orang lain yang membutuhkan tenaganya. Dengan pihak yang butuh tenaganya ini dia terlibat dalam hubungan kerja. Pemberi kerja biasanya di sebut majikan atau untuk pekerjaan-pekerjaan yang bersifat formal dan publik. Pelaksana pekerjaan atau penerima kerja di sebut buruh atau pekerja. Hubungan keduanya di atur dengan hukum perjanjian atau hukum kontrak. Oleh karena itu, untuk melihat hak dan kewajiban kedua belah pihak, maka membahas masalah perjanjian atau kontrak yan di buat oleh kedua pihak merupakan hal yang harus di lakukan.

Pada dasarnya hukum kontrak mempunya azas yang sangat penting untuk di kemukakan, apalagi bila akan menganalisis kontrak yang di buat oleh tenaga kerja Indonesia yang bekerja di luar negeri dengan majikannya. Kontrak yang mereka buat biasanya sama antara yang satu dengan yang lain dan biasanya di sebut dengan kontrak baku. Dalam menandatangani kontrak baku ini, terdapat kesan bahwa seakan-akan ada pihak yang tidak ikut serta membuat atau merumuskan pasal-pasal, sehingga seakan-akan pula ada pihak yang tidak bebas dalam mengimplementasikan keinginannya yang di tuangkan dalam kontrak tersebut. Secara teori pada dasarnya terdapat dua pendapat yang berbeda. Pendapat yang pertama mengatakan bahwa yang tidak ikut membuat; menandatangani kontrak baku terlanggar kebebasannya yang di jamin oleh azas-azas kebebasan berkontrak. Sedangkan pendapat yang kedua mengemukakan bahwa pihak yang tidak ikut merumuskan pasal-pasal dalam kontrak tetap mempunyai kebebasan untuk tidak menandatangani atau tidak menandatangani. Hanya ketika dia menandatangani, maka dia tidak lagi bebas menentukan kemauannya yang seharusnya bisa di tuangkan dalam kontrak.

Menurut Soebagjo (1993) dengan azas kebebasan berkontrak, para pihak mempunyai hak untuk menentukan apa saja yang di inginkannya dan sekaligus juga di perkenankan untuk menentukan apa yang tidak di kehendakinya untuk di cantumkan di dalam perjanjiannya, dan apa yang di perjanjikan itu akan mengikat para pihak yang menandatangani perjanjian tersebut (vide Pasal 1338 KUH-Perd). Akan 
tetapi, Soebagjo mengemukakan bahwa penerapan azas kebebasan berkontrak ini adalah tidak bebas sebebasnya. Beberapa pembatasan juga di terapkan oleh pembuat peraturan perundangundangan. Pembatasan yang di maksudkan adalah bahwa azas kebebasan berkontrak tersebut tidak boleh bertentangan dengan ketertiban umum, kepatutan dan kesusilaan. Dalam praktek kontrak baku akan semakin berkembang untuk keperluan-keperluan transaksi tertentu, seperti asuransi, kredit bank dan perjanjian kerja.

Dengan melihat adanya pendapat tentang kontrak baku tersebut, maka dapat ditelusuri pula dengan mengkaji adanya hubungan hukum antara para pihak yang membuat perjanjian dalam hal kedudukannya, bentuk dan sifatnya.

Telah di kemukakan bahwa dalam mengimplementasikan hak-haknya untuk mendapatkan pekerjaan dan penghidupan yang layak seseorang bisa bekerja secara mandiri tetapi ada pula yang bekerja pada orang lain. Apabila dia bekerja pada orang lain, maka dia akan melakukan hubungan kerja dengan pihak orang lain yang biasanya di sebut dengan majikan. Dalam hubungan kerja ini nampaknya secara yuridis mereka mempunyai kedudukan yang seimbang karena kedua belah pihak mempunyai kebebasan untuk membuat atau tidak membuat perjanjian kerja. Namun demikian ketika mereka membuat perjanjian, maka Pasal 1601a KUH-Perd ternyata kedudukan hukum antara keduanya sudah tidak seimbang karena perjanjian kerja di definisikan sebagai berikut:

" suatu perjanjian dimana pihak yang satu, buruh, mengikatkan diri untuk bekerja pada pihak yang lain, majikan, selama waktu tertentu dengan menerima upah"

Dari definisi tersebut yang secara eksplisit yang mengikatkan diri adalah buruh, sedangkan majikan tidak. Dan imbalan dari pengikatan dirinya tersebut dia menerima upah. Kalimat dalam pasal tersebut nampaknya sudah mempunyai keterpihakan bahwa seseorang yang hanya mempunyai tenaga harus mengikatkan dirinya dengan seseorang yang memperkerjakan dia. Dari hal ini nampak bahwa hubungan hukumnya sudah berbeda. Walaupun Soepomo (1982) mengemukakan bahwa secara yuridis hubungan hukum antara majikan dan buruh bebas dan secara sosiologis tidak, tetapi yang jelas bahwa strata ekonomis keduanya memang berbeda. Apalagi kalau di lihat dari sisi demografis dimana jumlah penduduk yang banyak makin merendahkan posisi tawar seseorang yang hanya mempunyai tenaga saja. Hal yang demikian itu 
masih di tambah lagi dengan adanya kontrak baku bagi tenaga kerja yang bekerja di luar negeri. Jadi jelas bahwa kedudukan, bentuk dan sifat hubungan hukum antara kedua pihak tidak lagi seimbang. Oleh karena itu, pihak yang lemah kedudukannya atau posisi tawarnya memerlukan perlindungan hukum.

\section{Paradigma Pengaturan Perlindungan TKI.}

Dalam UU PPTKILN telah dikemukakan dalam latar belakang, bahwa berdasarkan jumlah pasal, maka pasal yang mengatur tentang penempatan jauh lebih banyak dari pada pasal yang mengatur tentang perlindungan, tapi sebelum memerinci tentang hal itu, dianalisis terlebih dahulu tentang filosofi UU PPTKILN ini dalam konsiderans, asas, dan tujuannya.

Dalam konsiderans a-i garis besarnya adalah penghormatan hak asasi manusia untuk bekerja; kedua hak dan kesempatan yang sama tanpa diskriminasi; perlindungan terhadap akan terjadinya perdagangan manusia, kewajiban negara berdasarkan prinsipprinsip yang tercantum dalam asas pada Pasal 2 UU PPTKILN; penempatan; ketepaduan dalam penempatan antara pemerintah pusat dengan daerah serta peran serta masyarakat dalam suatu sistem hukum untuk melindungi; terakhir dikemukakan tentang belum adanya peraturan perundangan yang mengatur. Adapun konsideran dari UU PPTKILN adalah sebagai berikut :

(a) bahwa bekerja merupakan hak asasi manusia yang wajib dijunjung tinggi, dihormati, dan dijamin penegakannya; (b) bahwa setiap tenaga kerja mempunyai hak dan kesempatan yang sama tanpa diskriminasi untuk memperoleh pekerjaan dan penghasilan yang layak, baik di dalam maupun di luar negeri sesuai dengan keahlian, keterampilan, bakat, minat,dan kemampuan; (c) bahwa tenaga kerja Indonesia di luar negeri sering dijadikan obyek perdagangan manusia, termasuk perbudakan dan kerja paksa, korban kekerasan, kesewenang-wenangan, kejahatan atas harkat dan martabat manusia, serta perlakuan lain yang melanggar hak asasi manusia; (d) bahwa negara wajib menjamin dan melindungi hak asasi warga negaranya yang bekerja baik di dalam maupun di luar negeri berdasarkan prinsip persamaan hak, demokrasi, keadilan sosial, kesetaraan dan keadilan gender, anti diskriminasi, dan anti perdagangan manusia; (e) bahwa penempatan tenaga kerja Indonesia di luar negeri merupakan suatu upaya untuk mewujudkan hak dan kesempatan yang sama bagi tenaga kerja untuk memperoleh pekerjaan dan 
penghasilan yang layak, yang pelaksanaannya dilakukan dengan tetap memperhatikan harkat, martabat, hak asasi manusia, dan perlindungan hukum serta pemerataan kesempatan kerja dan penyediaan tenaga kerja yang sesuai dengan kebutuhan nasional; (f) bahwa penempatan tenaga kerja Indonesia di luar negeri perlu dilakukan secara terpadu antara instansi Pemerintah baik Pusat maupun Daerah dan peran serta masyarakat dalam suatu sistem hukum guna melindungi tenaga kerja Indonesia yang ditempatkan di luar negeri; (g) bahwa peraturan perundang-undangan di bidang ketenagakerjaan yang ada belum mengatur secara memadai, tegas, dan terperinci mengenai penempatan dan perlindungan tenaga kerja Indonesia di luar negeri; (h) bahwa dalam Undangundang Nomor 13 Tahun 2003 tentang Ketenagakerjaan dinyatakan penempatan tenaga kerja Indonesia di luar negeri diatur dengan undangundang; (i) bahwa berdasarkan pertimbangan sebagaimana dimaksud dalam huruf a, huruf $b$, huruf $c$, huruf $d$, huruf e, huruf f, huruf g, dan huruf h, perlu membentuk Undang-undang tentang Penempatan dan Perlindungan Tenaga Kerja Indonesia di Luar Negeri.

$$
\text { Apabila dilihat substansi }
$$

konsiderans, maka telah menampakkan kerangka dalam pengaturan pasal- pasalnya, perhormatan terhadap hak asasi, anti diskriminasi, perlindungan, baru penempatan dan keterpaduan antara pemerintah pusat dengan pemerintah daerah dan peran serta masyarakat, tetapi pada bagian badannya dimulai dari tugas dan tanggung jawab pemerintah; hak dan kewajiban TKI; langsung pelaksanaan penempatan; tata cara penempatan; baru perlindungan; penyelesaian perselisihan; pengawasan; BNP2TKI; sanksi administratif; penyidikan; ketentuan pidana dan terakhir: ketentuan lain-lain, ketentuan peralihan dan ketentuan penutup.

Dari kedua deskripsi tersebut, nampak bahwa antara konsiderans menimbang dengan bab-bab dan isi pasalnya menunjukkan adanya inkonsistensi. Asas dan tujuan yang tercantum dalam pasal 2 dan 3 terdapat beberapa kritik. Adapun ketentuan Pasal 2 dan 3 UU PPTKILN adalah sebagai berikut :

Pasal 2

Penempatan dan perlindungan calon TKI/TKI berasaskan keterpaduan, persamaan hak, demokrasi, keadilan sosial, kesetaraan dan keadilan gender, anti diskriminasi, serta anti perdagangan manusia.

Pasal 3

Penempatan dan perlindungan calon TKI/TKI bertujuan untuk : 
a. memberdayakan dan mendayagunakan tenaga kerja secara optimal dan manusiawi;

b. menjamin dan melindungi calon TKI/TKI sejak di dalam negari, di negara tujuan, sampai kembali ke tempat asal di Indonesia;

c. meningkatkan kesejahteraan TKI dan keluarganya.

Pasal 2 persis sama dengan yang ada di konsiderans menimbang, hanya ditambah dengan "keterpaduan". Dalam praktek, terdapat hal penting yang tidak menjadi prinsip, yakni peran serta TKI dan masyarakat serta transparansi. Ketiga hal ini dapat menjadi saluran dalam pembuatan kebijakan yang terkait dengan TKI. Sedangkan tujuannya masih terlalu umum dan nampak 'komoditisasi'-nya karena tujuan pertama walaupun ada kata 'memberdayakan' di awal kalimat, tetapi kalimat lanjutannya 'mendayagunakan tenaga kerja secara optimal' dapat berimplikasi buruk karena dapat diartikan dengan menggunakan sedemikian rupa, termasuk menjadi sarana untuk 'menjaga' nilai tukar rupiah sehingga 'membantu atau mensubsidi' para pengusaha besar untuk tidak merugi ketika berdagang menggunakan standar mata uang asing. Juga dapat diinterpretasikan sebagai 'jalan keluar' ketika pemerintah tidak mampu memenuhi hak asasi warga negara untuk mendapatkan pekerjaan dan penghidupan yang layak bagi kemanusiaan. Oleh karena itu, apabila ada usulan perubahan UU PPTKILN hendaknya ditambahkan tujuan: (1) menberikan dan menjamin perlindungan kepada calon TKI/TKI sejak di dalam negari, di negara tujuan, ketika kembali ke tempat asal dan pasca bekerja di luar negeri; (2) menjamin pemenuhan dan penegakan hak asasi TKI sebagai manusia dan sebagai tenaga kerja; (3) menjamin bahwa TKI dan keluarganya ikut berpartisipasi dalam pengambilan keputusan yang menyangkut nasib TKI; (4) menjamin pendataan dan adminsitrasi yang baik; (5) mendorong terwujudnya kinerja yang baik antara pihak-pihak pemerintah, PJTKI, calon TKI/TKI dalam menjalankan kegiatan perlindungan dan penempatan TKI; (6) mendorong adanya alokasi dana APBN dan APBD untuk membiayai perlindungan TKI. Selain tambahan tersebut hendaknya menghilangkan tujuan pertama terutama 'mendayagunakan tenaga kerja secara optimal'.

Terkait dengan masalah paradigma dalam penyusunan perubahan UU PPTKILN, maka pendapat dari Jaringan Advokasi Revisi UU PPTKLN (JARI PPTKLN) sangat baik untuk digunakan 
sebagai landasan kehati-hatian dalam membuat pasal-pasal dalam undangundang yang akan dibuat.

Judul Undang-Undang nomor 39 tahun 2004 adalah Penempatan dan Perlindungan TKI di Luar Negeri. Ini menunjukkan konstruksi berpikir bahwa yang urgen adalah persoalan penempatan. Perlindungan merupakan kebutuhan berikutnya dalam keseluruhan proses penempatan. Ini menunjukkan logika yang menempatkan "perlindungan" hanyalah bagian kecil dari kebutuhan aturan penempatan. Logika ini terbukti dari pasal-pasal dalam undang-undang yang didominasi oleh persoalan 'tata niaga' TKI.

Urgensi pengaturan 'tata niaga' TKI menunjukkan secara jelas paradigma TKI sebagai komoditi dan konstruksi berpikir pragmatis yang bias ekonomi. Ketika arus migrasi menunjukkan trend yang semakin meningkat, maka kalangan entrepreuner melihatnya sebagai peluang bisnis. Muncullah bisnis penempatan TKI ke luar negeri yang semakin menjanjikan keuntungan besar. Buktinya, jumlah PJTKI dari tahun ke tahun semakin meningkat. Demikian juga dengan calo-calo yang mencari calon-calon TKI untuk direkrut, kian merajalela. Dalam kondisi seperti ini, posisi TKI di hadapan calo dan PJTKI sangatlah lemah. Sebab calo dan PJTKI- lah satu-satunya sumber informasi bagi mereka. Merekalah yang menguasai informasi tentang peluang kerja di luar negeri dan tentang prosedur bekerja di luar negeri. Para perempuan muda yang berpendidikan rendah dan miskin secara ekonomi dan informasi itu pada akhirnya menjadi obyek bisnis penempatan TKI.

Dari tulisan tersebut nampak bahwa apabila tidak berhati-hati dalam pembuatan pasal-pasal yang mengatur perusahaan yang menempatkan TKI akan terjadi 'komoditisasi', keleluasaan dan keuntungan yang diberikan oleh peraturan akan memunculkan pertumbuhan perusahaan yang luar biasa jumlahnya. Hal ini dapat dilihat dengan adanya pemusatan SIUP di Kementerian, deposit yang hanya 500 juta, calo yang dibiarkan berkeliaran, tidak dilaksanakannya pengaturan tentang adanya perjanjian penempatan antara calon TKI dengan PJTKI, penampungan yang menjadi tempat 'pemerasan' karena biaya hidup di penampungan yang dibebankan kepada TKI.

Kelemahan pengawasan dan/atau pengabaian oleh pejabat pemerintah yang diberikan tugas untuk melindungi, mengakibatkan keuntungan yang berlipat ganda bagi perusahaan, apalagi penegakan hukum di Indonesia saat ini dalam keadaan yang sulit dengan adanya 
mafia peradilan. Dengan demikian, mengubah paradigma penempatan yang mengatur tata niaga tersebut menjadi paradigma perlindungan dalam peraturan yang akan datang menjadi hal yang penting. Pemusatan pengaturan penempatan seharusnya berdasarkan pertimbangan perlindungan, bukan memberikan keleluasaan untuk mendapatkan keuntungan, karena yang 'dikirim' atau 'ditempatkan' adalah manusia yang punya harkat dan martabat yang dijamin perlindungannya dalam pembukaan UUD 1945 dan pasal-pasal yang ada di dalamnya.

\section{Perlindungan Hukum TKI dan Kebijakan Moratorium}

Perlindugan merupakan kata yang demikian penting akhir-akhir ini, terutama setelah terjadinya amandemen UUD 1945 yang pada amandemen keduanya telah memerinci hak asasi manusia dengan menambah pasal 28 pada huruf a sampai dengan $\mathrm{j}$, dan hak asasi yang berkaitan dengan TKI ada pada pasal 27 ayat (2) dan 28 yang telah diamandemen berikut:

\section{Pasal 27}

(2) Tiap-tiap warganegara berhak atas pekerjaan dan penghidupan yang layak bagi kemanusiaan.

Pasal 28C
(1) Setiap orang berhak mengembangkan diri melalui pemenuhan kebutuhan dasarnya, berhak mendapat pendidikan dan memperoleh manfaat dari ilmu pengetahuan dan teknologi, seni dan budaya, demi meningkatkan kualitas hidupnya dan demi kesejahteraan umat manusia.

(2) Setiap orang berhak untuk memajukan dirinya dalam memperjuangkan haknya secara kolektif untuk membangun masyarakat, bangsa, dan negaranya.

Pasal 28D

(1) Setiap orang berhak atas pengakuan, jaminan, perlindungan dan kepastian hukum yang adil serta perlakuan yang sama di hadapan hukum.

(2) Setiap orang berhak untuk bekerja serta mendapat imbalan dan perlakuan yang adil dan layak dalam hubungan kerja.

(3) Setiap warga negara berhak memperoleh kesempatan yang sama dalam pemerintahan.

(4) Setiap orang berhak atas status kewarganegaraan.

Pasal 28E

(1) Setiap orang bebas memeluk agama dan beribadat menurut agamanya, memilih pendidikan dan pengajaran, memilih pekerjaan, memilih kewarganegaraan, memilih tempat 
tinggal di wilayah negara dan meninggalkannya serta berhak kembali.

(2) Setiap orang berhak atas kebebasan meyakini kepercayaan, menyatakan pikiran dan sikap sesuai dengan hati nuraninya.

(3) Setiap orang berhak atas kebebasan berserikat, berkumpul, dan mengeluarkan pendapat.

\section{Pasal 28F}

Setiap orang berhak untuk berkomunikasi dan memperoleh informasi untuk mengembangkan pribadi clan lingkungan sosialnya, serta berhak untuk mencari, memperoleh, memiliki, menyimpan, mengolah, dan menyampaikan informasi dengan menggunakan segala jenis saluran yang tersedia.

Kelima pasal dalam UUD 1945 ini merupakan dasar yang digunakan untuk pembuatan pasal-pasal mengenai perlindungan dalam UU Perlindungan TKI yang akan datang karena pasalpasal tersebut merupakan hak asasi manusia yang terkait dengan orang yang bekerja ke luar negeri. Pasal 27 ayat (2) UUD 1945 merupakan hak yang seharusnya dipenuhi oleh pemerintah terhadap setiap warga negara, pasal 28C, merupakan hak yang penting bagi calon
TKI dan TKI, karena hak untuk mendapat pendidikan dan memperoleh manfaat dari ilmu pengetahuan untuk meningkatkan kualitas hidupnya dijamin oleh UUD 1945. Pasal berikutnya adalah pasal 28D, di mana dikemukakan bahwa setiap orang berhak atas pengakuan, jaminan, perlindungan dan kepastian hukum yang adil serta perlakuan yang sama di hadapan hukum. Demikian pula hak untuk mendapat imbalan dan perlakuan yang adil dan layak dalam hubungan kerja. Kebebasan untuk memeluk agama dan beribadat menurut agamanya dijamin dalam pasal 28E, juga kebebasan berserikat berkumpul dan mengeluarkan pendapat. Hak yang mendasar dalam bekerja di luar negeri yang saat ini banyak menimbulkan persoalan adalah hak untuk berkomunikasi dan mendapatkan informasi yang dalam ketentuan UUD 1945 dicantumkan dalam pasal 28. Berdasarkan hak-hak yang ada dalam konstitusi tersebut, maka dalam melakukan revisi UU PPTKILN selalu menggunakan pasal-pasal tersebut sebagai dasar dalam UU yang baru.

Dalam pada itu, berbicara tentang perlindungan hukum, maka hal tersebut merupakan bentuk konsekuensi dari suatu bentuk negara hukum, di mana "negara Indonesia berdasar atas hukum (rechtstaat) tidak berdasarkan atas 
kekuasaan belaka (machtstaat)". Pemerintah berdasarkan konstitusi tidak bersifat absolut (Sudjono, 1989 : 16). Perlindungan hukum adalah memberikan pengayoman kepada hak asasi manusia yang dirugikan orang lain dan perlindungan tersebut diberikan kepada masyarakat agar mereka dapat menikmati semua hak-hak yang diberikan oleh hukum. Hukum merupakan bagian yang tidak dapat dipisahkan dari kehidupan manusia. Hukum senantiasa mengatur dan menguasai manusia dalam kehidupan sosialnya. Dengan demikian, maka tata hukum bertolak pada penghormatan perlindungan bagi manusia. Penghormatan dan perlindungan hukum bagi manusia tidak lain merupakan pencerminan dari kepentingan pribadi. Hukum terdapat di dalam masyarakat. Demikian juga sebaliknya, dalam masyarakat selalu ada sistem hukum sebagaimana adagium "ubi societas, ibi ius" (Mertokusumo, 1999 : 14).

Pada intinya, perlindungan hukum adalah perlindungan terhadap harkat dan martabat serta pengakuan terhadap hakhak asasi manusia yang dimiliki oleh subyek hukum berdasarkan ketentuan hukum dari kesewenang-wenangan. Perlindungan hukum adalah berbagai upaya hukum yang harus diberikan oleh aparat penegak hukum untuk memberikan rasa aman, baik secara pikiran maupun fisik dari gangguan dan berbagai ancaman dari pihak manapun. Perlindungan hukum juga dapat diartikan sebagai kumpulan peraturan atau kaidah yang akan dapat melindungi suatu hal dari hal lainnya.

Istilah perlindungan hukum merupakan penyempitan arti dari perlindungan, dalam hal ini hanya perlindungan oleh hukum saja. Perlindungan yang diberikan oleh hukum, terkait pula dengan adanya hak dan kewajiban, dalam hal ini yang dimiliki oleh manusia sebagai subyek hukum dalam interaksinya dengan sesama manusia serta lingkungannya. Sebagai subyek hukum manusia memiliki hak dan kewajiban untuk melakukan suatu tindakan hukum.

Prinsip perlindungan hukum terhadap tindakan pemerintah bertumpu dan bersumber dari konsep tentang pengakuan dan perlindungan terhadap hak-hak asasi manusia karena menurut sejarahnya di barat, lahirnya konsepkonsep tentang pengakuan dan perlindungan terhadap hak-hak asasi manusia diarahkan kepada pembatasanpembatasan dan peletakan kewajiban masyarakat dan pemerintah. Aspek dominan dalam konsep barat tentang hak asasi manusia menekankan eksistensi hak dan kebebasan yang melekat pada 
kodrat manusia dan statusnya sebagai individu, hak tersebut berada di atas negara dan di atas semua organisasi politik dan bersifat mutlak sehingga tidak dapat diganggu gugat. Oleh karena itu, sering kali dilontarkan kritik bahwa konsep barat tentang hak-hak asasi manusia adalah konsep yang individualistik. Kemudian dengan masuknya hak-hak sosial dan hak-hak ekonomi serta hak kultural, terdapat kecenderungan mulai melunturnya sifat indivudualistik dari konsep barat (Hadjon, 1987 : 49).

Dalam merumuskan prinsip-prinsip perlindungan hukum di Indonesia, landasannya adalah Pancasila sebagai ideologi dan falsafah negara. Konsep perlindungan hukum bagi rakyat di Barat bersumber pada konsep-konsep rechtstaat dan rule of the law. Prinsip perlindungan hukum terhadap tindakan pemerintah bertumpu dan bersumber dari konsep tentang pengakuan dan perlindungan terhadap hak-hak asasi manusia karena menurut sejarahnya di barat, lahirnya konsep-konsep tentang pengakuan dan perlindungan terhadap hak-hak asasi menusia diarahkan kepada pembatasan-pembatasan dan peletakan kewajiban masyarakat dan pemerintah.

Jadi perlindungan hukum adalah perlindungan akan harkat dan martabat serta pengakuan terhadap hak asasi manusia yang dimiliki oleh subyek hukum di dalam suatu negara berdasarkan perlindungan hukum dari kesewenang-wenangan (Hadjon, 1987 : 205). Terdapat 2 (dua) macam bentuk perlindungan hukum, yaitu : (1) perlindungan hukum preventif: di dalam perlindungan ini, hukum diberi kesempatan untuk mengajukan keberatan (inspraak) atau pendapatnya sebelum suatu keputusan pemerintah mendapat bentuk yang definitif. Perlindungan hukum preventif bertujuan untuk mencegah terjadinya sengketa antara pemerintah dengan rakyat: (2) perlindungan hukum represif; perlindungan hukum ini bertujuan untuk menyelesaikan sengketa yang dilakukan oleh lembaga peradilan, yaitu peradilan umum dan peradilan administrasi di Indonesia (Hadjon, 1987 : 36 - 37).

Perlindungan hukum terhadap masyarakat atau warga negara di Indonesia yang kurang maksimal disebabkan karena penegakan hukum yang ada juga masih sangat kurang. Perlindungan oleh pemerintah terhadap warga negaranya dalam segala bidang merupakan kewajiban yang tidak dapat diabaikan. Perlindungan hukum bagi rakyat diarahkan kepada usaha untuk mencegah terjadinya sengketa antara pemerintah dan rakyat, menyelesaikan sengketa secara musyawarah, serta 
peradilan merupakan sarana terakhir dalam usaha penyelesaian sengketa antara pemerintah dan rakyat (Hadjon, 1987 : 210).

Dengan demikian apabila perlindungan hukum dibuat dalam suatu peraturan perundangan, maka substansi yang ada dalam peraturan harus mencantumkan berbagai hal sebagai berikut :

1) yang mengatur mengenai hak yang dijamin dalam undang-undang secara eksplisit dan jelas;

2) persyaratan bagi subyek hukum yang memperoleh hak tersebut secara rinci;

3) pihak yang wajib memenuhi hak yang dijamin;

4) sanksi bagi pihak yang wajib memenuhi hak tetapi tidak meleksanakan;

5) pengaturan tentang prosedur untuk mendapatkan hak;

6) lembaga tempat complain ketika haknya tidak dipenuhi;

7) waktu maksimal untuk memenuhi hak setelah complain.

Pada point 7 dapat dicantumkan dalam peraturan pelaksanaannya yang bisa berwujud peraturan pemerintah atau peraturan presiden.
Dalam UU PPTKILN substansi yang mengatur tentang pemberian perlindungan sebagaimana keharusan tersebut di atas adalah:

(1) hak dan kewajiban ada pada pasal 8 huruf a sampai dengan i dan pasal 42 dan 77, walaupun ada juga secara implicit dalam pasal-pasal penempatan, sehingga sulit diterapkan; pasal-pasal 8 memang telah jelas dan eksplisit, pasal 42 mengenai hak atas pendidikan dan pelatihan yang sesuai dengan pekerjaan yang akan dilakukan di negara tujuan, sedangkan pasal 77 hak atas perlindungan di seluruh proses penempatan.

(2) persyaratan tentang subyek hukum yang dilindungi diatur dalam ketentuan umum, yakni pasal 1 angka 1 dan 3;

(3) pihak yang memenuhi hak yang dijamin adalah: (a) Pemerintah sebagaimana yang tercantum dalam pasal 6 yang mengatur tentang tanggung jawab untuk meningkatkan upaya perlindungan; (b) memberikan perlindungan pada pasal 7 huruf e; (c) Perwakilan Republik Indonesia di luar negeri melindungi TKI selama di negara tujuan sebagaimana dalam pasal 78 ayat (1) dan Atase Ketenagakerjaan dalam pasal 78 ayat (2); (d) PPTKIS 
bertanggung jawab atas perlindungan tapi hanya sesuai dengan perjanjian penempatan sebagaimana tercantum dalam pasal 82 ;

(4) sanksi bagi pihak yang wajib memenuhi hak tetapi tidak dilaksanakan tercantum dalam pasal 100 tentang administratif, pasal 102 tentang sanksi pidana penjara, pasal 104 tentang sanksi pidana kurungan;

(5) waktu untuk memperoleh hak adalah selama proses pra penempatan, saat penempatan dan masa purna penempatan tercantum pada pasal 7 huruf e; pasal 78 ayat (1) dan (2); pasal PPTKIS sebagaimana tercantum dalam pasal 82 tidak jelas waktunya.

(6) sedangkan prosedur untuk mendapatkan haknya tidak ada;

(7) demikian pula lembaga complain untuk mendapatkan hak juga tidak ada; dan

(8) waktu maksimal setelah complain juga tidak ada.

Dalam hal perlindungan preventif seharusnya melaksanakan: pemberian informasi tentang hak-hak yang dimiliki oleh subyek hukum, dalam hal ini semua pihak yang diberi kewajiban harus menjalankan kewajiban untuk memberikan informasi tentang hakhaknya, pihak yang wajib memenuhi hak, prosedur mendapatkan hak, dan lembaga komplain. Jadi dalam UU PPTKILN yang wajib menginformasikannya adalah Pemerintah, Perwakilan RI di luar negeri dan atau Atase Ketenagakerjaan, PPTKIS dan BNP2TKI.

Terkait tata cara pengiriman TKI ke suatu negara tujuan dalam ketentuan UU PPTKILN telah mensyaratkan adanya suatu perjanjian tertulis dibidang ketenagakerjaan yang menjamin perlindungan hak-hak TKI di negara tujuan. Hal tersebut telah diatur dalam pasal 27 UU PPTKILN sebagai berikut :

1. Penempatan TKI di luar negeri hanya dapat dilakukan ke negara tujuan yang pemerintahnya telah mempuat perjanjian tertulis dengan Pemerintah Republik Indonesia atau tenaga kerja asing.

2. Berdasarkan pertimbangan sebagaimana dimaksud ayat (1) dan/atau pertimbangan keamanan Pemerintah menetapkan negaranegara tertentu tertutup bagi penempatan TKI dengan Peraturan Menteri.

Sedangkan dalam ketentuan pasal 81 UU PPTKILN telah memfasilitasi pemerintah untuk melakukan upaya perlindungan bagi TKI dengan 
menerapkan

kebijakan

penghentian/moratorium

pengiriman

TKI.

\section{Simpulan}

Adapun kesimpulan yang dapat diambil dalam penelitian ini adalah pemberlakuan moratorium yang bertujuan untuk lebih memberikan perlindungan bagi TKI khususnya bidang domestik. Dengan pemberhentian pengiriman TKI ke luar negeri diharapkan Pemeritah Indonesia dapat menekan negara tujuan TKI untuk membuat Bilateral Agreement yang bertujuan memberikan perlindungan TKI. Dengan adanya penghentian pengiriman TKI juga akan meningkatkan skill TKI.

\section{Daftar Pustaka}

\section{Buku}

Abdul Hakim G. Nusantara, 1998, Politik Hukum Indonesia, Jakarta : Penerbit Yayasan Lembaga Bantuan Hukum Indonesia.

Castles dan Miller, 2009, The Age of Migration: International Population Movements in the Modern World, 4th edition, New York : Guilford Press.

Douglas Massey, et al, 2008, Theories of International Migration: A Review and Appraisal.
JARI PPTKLN, 2010, Draft Naskah Akademik Revisi UU PPTKLN, Jakarta.

H. Braverman, 1974, Labor and Monopoly Capital: the Degradation of Work in the Twentieth Century, , New York and London : Monthly Review Press.

H.S. Kartadjoemena, 1996, GATT dan WTO, Sistem, Forum dan Lembaga Internasional di Bidang Perdagangan, Jakarta : UI Press.

L.M. Friedman, 1977, Law and Society : an Introduction, Prentice Hall, Inc., Englewood Cliffs, New Jersey.

Maria Patricia Fernandes Kelly, 1983, For We Are old, I And My People, Albany : State University of New York Press.

Philipus M. Hadjon, 1987, Perlindungan Hukum Bagi Rakyat Indonesia, Surabaya : Bina Ilmu.

Saukarto Marmo Sudjono, 1989, Penegakan Hukum di Negara Pancasila, Jakarta : Penerbit Garuda Metropolis Pers.

Soerjono Soekanto, 2002, Faktor-faktor yang Mempengaruhi Penegakan Hukum, Jakarta : Raja Grafindo Persada.

Sudikno Mertokusumo, 1999, Mengenal Suatu Hukum Pengantar, Yogyakarta : Penerbit Liberty.

Van L.J, Apeldorn, 1996, Pengantar Ilmu Hukum, Jakarta : Pradnya Paramita. 


\section{Jurnal}

Bagir Manan, 2005, "Penegakan Hukum yang Berkeadilan", Varia Peradilan, Tahun XX Nomor 241, Jakarta Pusa : Penerbit IKAHI.

M.A.S. Hikam, 1990; "Perlawanan Sosial: Telaah Teoritis dan
Beberapa Studi Kasus" dalam Prisma; Nomor 8 Tahun XIX.

\section{Website}

Jayati Ghosh, Migration And Gender Empowerment : Recent Trends And Emerging Issues, http://www.networkideas.org/ featart/mar2009/Migration.pdf , pada tanggal 27 Maret 2010. 